\title{
The Political Limitations of Evidence: A Critique of the Electoral Reform Society's It's Good To Talk
}

\author{
MICHAEL CUNNINGHAM
}

\begin{abstract}
The Electoral Reform Society has called for more and better quality information to improve democratic debate in relation to referendums. This article argues that, particularly in relation to the European Union referendum, this would have had a marginal impact, because much of the debate was not reducible to facts and emotional and dispositional factors were of particular significance in the campaign.
\end{abstract}

Keywords: European Union, referendum, Electoral Reform Society, Remain, Brexit

In SEPTEMBER 2016, the Electoral Reform Society (ERS) published a review of the European Union (EU) referendum of June 2016, entitled It's Good To Talk (IGTT), which included critiques of aspects of its operation and recommendations for the running of future referendums to ensure a better informed public and a more deliberative and dialogic system of politics. While these may be laudable aims, some of the review's observations about the EU referendum exhibit a conceptualisation of information and evidence in a political context which is naïve and overly positivist and involves some questionable assumptions about the operation of politics. I address these issues under four main themes, which are largely inter-connected: the status of information and evidence; the question of contingency and uncertainty; campaign negativity; and the role of identity, disposition and culture in positions adopted, and sides taken, in the referendum. Perhaps a disclaimer should be posted here: I am not concerned with the more general advantages and disadvantages of the use of referendums in democracies, but rather with the weaknesses of the analysis of the EU campaign.

IGTT reported that research indicated that people were not receiving sufficient accurate information and the campaigns were not doing enough to provide high-quality information for voters'. ${ }^{1}$ The conclusion to the report contains the recommendation that 'an officially sanctioned data set might help to inform voters' and there could be intervention 'by independent sources when overtly misleading claims are made by official campaigners'. ${ }^{2}$ However, it is difficult to see what sort of information and data would have made a substantial difference to the debate. As the ERS recognises, all facts need to be interpreted and will be contested. An example to illustrate this is the question of the size of the European Commission bureaucracy. One might imagine that it would be relatively simple to establish this. The EU's own figures estimate it at approximately 33,000, as do sources sympathetic to the EU. ${ }^{3}$ It is claimed that this figure is small relative to some state and regional bureaucracies, and thus is evidence that the Commission's bureaucracy is not inefficient and bloated. ${ }^{4}$ However, this figure is contested by some eurosceptics, with one estimate from this side as high as $170,000 .^{5}$ The lower figure appears the more credible based on an examination of sources, as the higher one includes lobbyists and those outside the permanent bureaucracy, yet the 'facts', which are contested, do not settle the issue. My contention is that ideas of European bureaucracy (in terms of both excessive size and lack of accountability) are so ingrained in popular discourse that the facts are largely overlooked. Additionally, for Leavers the Commission lacks legitimacy, so that its size and relative efficiency are less the issue than its existence in the first place, and no evidence concerning its efficiency is likely to persuade. Therefore, more and 'better' facts about the European Commission, given how many 
were accessible, would have made little difference to the debate.

The Institute of Fiscal Studies (IFS) was viewed by many commentators as an organisation which strove for objectivity, but there is little evidence that its calculations or predictions had any great impact, in particular as it could be dismissed as another example of establishment 'expertise', and therefore not to be trusted, by those in the Brexit camp. ${ }^{6}$ The ERS, in association with three universities, established an online resource to provide information and a forum for discussion on the topics of social policy, migration and work, crime and security, regions and nations and economic impact. Such is the complexity and contentious nature of these areas that it is again difficult to see what 'facts' or information could be presented which would be accepted by most observers and potential voters beyond the most trivial, banal or irrelevant.

If an agency of intervention, as recommended by the ERS, had existed during the EU campaign, it is impossible to know if it would have had an impact. One must be sceptical on the basis that those criticised by it would probably have tried to impugn its independence however it was funded or whomever it was associated with. If it were government-funded or part of the civil service, it would have most likely been attacked by Brexit as a part of the 'establishment' and thus dismissed.

The general point here is that the unavoidable process of interpreting and contextualising 'facts' means that more or 'better' information is something of a red herring and would not have transformed the campaign. A second point is that, arguably, the topic of the referendum made the limitations of looking for facts and information to improve democratic debate particularly stark. Both sides were predicting how the UK would evolve and fare outside the EU and the pictures drawn were inevitably coloured by speculation, the amount of variables involved and contingencies. While some scenarios might seem more plausible than others, facts and information became even less relevant as the protagonists tried to give a vision of the UK (or possibly the UK without Scotland) ten years hence which had to factor in the responses of the USA, China and the EU, among other international actors, to the UK's departure. A moment's reflection on the variables involved and the predictive inadequacies of economists and other social scientists reveals how little impact recourse to facts or data will have in such an exercise. Neither of these two points is intended to support some extreme relativism or postmodern dismissal of facts; rather, the contention is that the availability of more or better information would have been marginal to the EU campaign in either its prosecution or outcome.

The next issue to be addressed is that of negativity. Both the electorate and the ERS criticised the degree of negativity in the campaign. ${ }^{7}$ Two issues will be discussed here. The first is a qualified defence of the use of negative campaigning by politicians and other activists; the second is the problem of a lack of definition and interrogation of what constitutes negativity. In a political campaign, parties or other campaigning groups will presumably try to maximise support through a variety of strategies and tactics, and it is not clear why critiques of opponents' positions should not be considered legitimate politics. ${ }^{8}$ One example cited in IGTT was the Remain campaign's estimates of the economic costs of leaving the EU. ${ }^{9}$ It is unclear whether is the principle of using the predicted economic costs which constitutes the negative campaigning to be deplored or the specific estimates detailed in the article. I would argue that neither should be considered a problem and to label such a strategy 'Project Fear', as did some of Remain's opponents, is facile. If the Remain camp believed, as it probably genuinely did, that leaving the EU would damage the UK's economy, it is legitimate politics to say so, and should not be dismissed as negative campaigning. The specific estimates of the costs may be dubious; as indicated above, it is unlikely that any specific calculations had a good evidential basis. However, the Remain camp presumably felt that, as a political strategy, giving some specific estimates would strengthen their case. If the Leave camp believed, as I argue, that the evidential base was weak, they were free to engage in a campaign of challenge and critique.

In the same paragraph in which Remain's economic estimates were detailed, IGTT gave 
three examples of Leave's negative statements. These were claims about potential mass immigration from Turkey, comments from Nigel Farage about sex attacks by immigrants and Boris Johnson's evocation of Nazism in relation to the EU's goals. Two observations will be made here. First, does this juxtaposition imply equivalence between the negativity of the two camps? It could be argued that contested economic predictions qualitatively differ from racial stereotyping or offensive jokes. However, this is not to argue that the latter should be proscribed in a political campaign. Beyond the legislative proscription against incitement, slander, and so on, there is an argument that the cut-andthrust of political debate and competition has to allow for the unevidenced, the offensive and the trivial, given the difficulty of establishing a consensus on the limits to negative campaigning. The prevailing political culture can act as a constraint upon such excesses. If sufficient numbers of the electorate dislike negativity, however defined, then it will penalise candidates and campaigners who employ it.

Second, what constitutes negativity or negative campaigning is not self-evident. It will depend in part on how political language is interpreted and the context in which it is used. One example from the EU referendum will illustrate this. The Leave campaign, and in particular Farage, used the slogan 'take our country back', or variations of it. For supporters of Leave, this could be interpreted as a rallying cry to reclaim sovereignty and autonomy in governance. However, some Remain supporters interpreted this slogan as implicitly racist or anti-immigrant, and for others it was a facile slogan that, wilfully or otherwise, failed to confront the complexities of global interconnections and the concept of national sovereignty in the twenty-first century. In this reading, Farage's slogan is negative in the sense that it was either racist, crudely populist, or failed to address the realities of contemporary global politics.

The final aspect of the EU referendum that raises doubts about the efficacy of increased information, data and, perhaps, dialogue is that some support for the two camps has been interpreted as representing two different political cultures or identities. ${ }^{10}$ Those who supported Remain- disproportionately the young, the formally well-educated and residents of big citieswere more supportive of a cluster of ideas around shared sovereignty, multiculturalism, cosmopolitanism and an identity that went beyond and superseded a British one. Leave supporters were a more heterogeneous group and encompassed both affluent, rural Conservative areas and post-industrial, workingclass areas. For some Leave supporters, the appeal lay in a more 'traditional' Britain (or, more frequently, England) which embodied an arguably outmoded conception of national sovereignty and a more homogenous cultural and racial composition. ${ }^{11}$ The European project was also often associated with a political elite which, for the working-class constituency, had failed to provide stable employment, affordable housing and adequate public services. Working-class support for Brexit was often interpreted by Remain supporters as a manifestation of the frustrations of those who had suffered economically in a period of deindustrialisation and globalisation. The argument is not that the material had no impact on the campaign, but rather that a broad cultural identity and political disposition was also significant. The importance of this is that the details of the workings of the EU, the possibility of institutional reform and the cost of its functioning (and debates therein) were of secondary importance. For many of the Remain and Leave supporters, the details of the functioning of the EU were of marginal significance. For many Remainers the EU was a symbol of, and had a symbolic value as, a positive, inclusive, post-national, unchauvinistic form of politics, whereas for many Leavers it symbolised a loss of national autonomy and British pride, and caused, or coincided with, economic decline and marginalisation.

\section{Conclusion: the positivist illusion}

Among other recommendations, the ERS calls for the provision of better quality and more objective information to improve political debate and to help with decision-making among the electorate. My argument is that such provision would have been of marginal significance in the EU referendum, for three reasons: one generic and two more specific to the referendum. Citizens and the electorate will not necessarily reject or ignore facts, but 
they will be filtered, interpreted and contextualised through pre-existing ideological affiliations, dispositions and understandings. Therefore, an officially sanctioned data set or something of that ilk would not necessarily be seen as objective or help electors choose a position. This is a general claim about knowledge and evidence in the social world. In the context of the EU debate, two more specific factors are important. As it was not a contest between the parties in the manner of a general election, there was no 'track record' of competence in government to be considered and debated by the electorate and, as indicated above, the debate was largely about the likely trajectory of the UK and the UK economy outside the EU. Therefore, hard data and uncontentious facts were even more sparse and marginal than in conventional political and electoral competition and discourse. Additionally, within the binary context of a referendum, EU membership was a symbol of the cultural direction of the UK, of which Remainers broadly approved, and which Leavers disliked. Inasmuch as the contest was about disposition, culture and identity, 'facts' about the operation of the EU as an institution or its 'real' impact on the UK economy since 1973 were largely irrelevant. This is not to claim that the electorate is irrational or atavistic. It is to argue, rather, that the positivist emphasis on facts, objectivity and evidence underestimates the role of emotion, ideology and identity in political affiliation and choice and overestimates the efficacy of improved and increased information.

\section{Notes}

1 W. Brett, It's Good To Talk: Doing Referendums Differently After the EU Vote, London, Electoral Reform Society, September 2016, p. 18.

2 Ibid, p. 55.

3 European Commission, 'Staff figures', http:// ec.europa.eu/civil_service/about/figures/inde x_en.htm (accessed 20 September 2016); Fullfact, 'EU facts behind the claims: "Brussels bureaucrats"', https://fullfact.org/europe/eufacts-behind-claims-brussels-bureaucrats/ (accessed 20 September 2016).

4 See, for example, thenewfederalist.eu, 'The EU administration: small and efficient', 26 June 2014, http://www.thenewfederalist.eu/the-euadministation-small-and-efficient (accessed 20 September 2016).

5 This was the estimate of Open Europe: C. Hope, 'EU bureaucrats outnumber British army two to one, say campaigners', The Telegraph, 10 August 2008, http://www.telegraph.co.uk/ne ws/worldnews/europe/2535295/EU-bureauc rats-outnumber-British-army-two-to-one-say-ca mpaigners.html (accessed 20 September 2016).

6 See C. Engineer, 'Thinktank warning of Brexit danger is part of "cosy" Remain establishment, claims Tory MP', Daily Express, 25 May 2016, http://www.express.co.uk/news/uk/673609/ john-redwood-ifs-eu (accessed 14 September 2016). For an IFS rejoinder, see IFS, 'We may not always be right, but to suggest as Nigel Farage did on Marr that IFS is biased by our funding is untrue', 12 June 2016, https:// www.ifs.org.uk/about/blog/351 (accessed 14 September 2016).

7 Brett, It's Good To Talk, p. 28.

8 For a more detailed discussion see W. G. Mayer, 'In defense of negative campaigning', Political Science Quarterly, vol. 111, no. 3, 1996, pp. 437-55.

9 Brett, It's Good To Talk, p. 26.

10 S. Bush, 'Divided Britain: how the EU referendum exposed Britain's new culture war', The New Statesman, 23 June 2016, http:/ / www.new statesman.com/politics/uk/2016/06/dividedbritain-how-referendum-exposed-britains-cul ture-war (accessed 14 September 2016). Many Remainers were cited as not recognising their country after the vote, or as feeling alienated from it, which indicated a feeling of cultural dislocation. See for example Paddy Ashdown, former Liberal Democrat leader: 'I said to my wife: this is not our country any more', The Guardian, 17 September 2016, p. 41.

11 For the correlation between an English identity and support for Brexit, see M. Kenny, 'The genesis of English nationalism', Political Insight, Political Studies Association, September 2016, pp. 8-11. 